\title{
CLAUSAL MODIFIERS IN NOUN PHRASES: A COMPARISON OF ENGLISH AND NORWEGIAN BASED ON THE OSLO MULTILINGUAL CORPUS
}

\author{
JOHAN ELSNESS \\ University of Oslo
}

\section{A B S T R AC T}

The structure of the noun phrase has many common features in English and Norwegian. One feature shared by the two languages is that noun phrases often contain clausal postmodifiers. However, there are marked differences in the types of clauses occurring: Postmodifying clauses in Norwegian tend to be finite relative clauses, while in English there is much more variation, connected with the general fact that -ing clauses and past-participle clauses are common non-finite alternatives in that language, in addition to infinitive clauses. These all tend to be less explicit modifiers than relative clauses, in terms of both their semantic content and their syntactic structure. The study reported in this article confirms that Norwegian noun phrases are often characterised by a higher degree of explicitness than corresponding English ones. A major finding is a tendency for information which is expressed by clausal noun-phrase modifiers in English to be expressed by other means in Norwegian, sometimes outside the same noun phrase, which can often be seen as the extreme case of explicitness. The study is based on an investigation of corresponding noun phrases in the English-Norwegian Parallel Corpus (ENPC), part of the Oslo Multilingual Corpus. In an attempt to offset the impact of individual translators' preferences, the Multiple-translation Corpus, consisting of ten different Norwegian translations of each of two English Original texts, is also examined.

\section{[1] INTRODUCTION}

Although English and Norwegian are closely related languages both genetically and typologically, there are some notable differences in the structure of the noun phrase between the two languages. In this article the focus will be on some of the clausal modifiers which occur in the noun phrases of the two languages, where some striking differences have been noted, one of them being that non-finite clauses acting as modifiers of nouns seem to be distinctly more common in English than in Norwegian. One reason for that is that -ing clauses, a common modifier type in English, have no straightforward equivalent in Norwegian. In many cases they will be matched by finite relative clauses in Norwegian: -a lady driving 
a red car vs. en dame som kjører en rød bil. ${ }^{1}$ Another type of non-finite modifier usually held to be quite common in English is past-participle clauses, as in a topic discussed before. The equivalent construction in Norwegian, et emne diskutert for, is more marginal. English also has a non-finite relative clause type with no direct parallel in Norwegian, the relative pronoun acting as a prepositional complement and the verb appearing in the infinitive: a good place in which to grow up, a suitable point from which to start. No parallel construction exists in Norwegian, although an infinitive clause without any relative may serve a similar function, with or without preposition: et godt sted å vokse opp (på), et passende punkt å starte fra. ${ }^{2}$ See further Table 1.

TABLE 1: Some noun-phrase structures in English and Norwegian. Modifiers in bold, examples of constructions unique to one language in italics.

\begin{tabular}{|c|c|c|}
\hline MODIFIER & ENGLISH & NORWEGIAN \\
\hline Postmodifying infinitive cl. & a man to trust & en mann å stole på \\
\hline Postmodifying pres. pcl. cl. & a lady driving a red car & - \\
\hline Postmodifying past pcl. $\mathrm{cl}$. & a topic discussed before & et emne diskutert før \\
\hline Finite relative clause & a lady who wants to go & en dame som vil gå \\
\hline Infinitival relative clause & a good place in which to grow up & - \\
\hline Apposition & the fact that he left & det faktum at han dro \\
\hline & rst husband & Alex, hennes første mann \\
\hline
\end{tabular}

Noun-phrase structures in English are treated in some detail by Quirk et al. $(1985,1350 f f$.$) , who present frequencies in a sample of some 17,000 noun phrases$ from the Survey of English Usage, putting the main emphasis on the variation recorded according to text category. In their count are included noun phrases headed by pronouns and names as well as those with regular common nouns as heads. Those pronouns and names constitute nearly half their sample. They find that overall less than one-third of the noun phrases in their material are complex in the sense of containing more than just a single pronoun or noun (common or proper, with or without determiner). The highest proportion of complexity is recorded in Scientific writing, which is further characterised by a high degree of complexity even in subject noun phrases, a function where simple noun phrases predominate in the other text categories distinguished.

Biber et al. (1999) report the results of a more finely grained analysis of nounphrase structures. Like Quirk et al. (1985) they find that complex noun phrases, especially those with both premodifiers and postmodifiers, are most common in Academic writing and least common in Conversation (Biber et al. 1999, 578). Within their group of postmodifiers prepositional phrases are by far the most common construction type, making up $65-80$ per cent of all postmodifiers in

[1] In this and subsequent examples bold font is used to indicate focused modifiers and other elements.

[2] For a collection of studies of the complexities of noun-phrase structures in various European languages, see (Plank 2003). 
all their four text categories ('registers') (Biber et al. 1999, 606), a result which agrees well with the 3-POS-grams set out in Table 2 below. On the whole, they find postmodification to be most common in News and Academic prose and least common in Conversation. After prepositional phrases relative clauses constitute the most frequent postmodifier type, especially in Fiction, followed by past-participle clauses and -ing clauses. Appositional clauses are fairly common in News and Academic prose, while they record a comparatively low proportion of infinitive clauses in all text categories (Biber et al. 1999, 606).

As regards comparison with Norwegian, Johansson \& Lysvåg $(1987,72,87)$ make the point that English -ing and past-participle clauses are generally matched by full relative clauses in Norwegian, although they add that in formal style Norwegian may have the past participle in more complex premodifying structures. Hasselgård et al. $(2012,352)$ note that even Norwegian may have postmodifying past-participle clauses as an alternative to relative clauses. One of their examples is:

(1) Helions monumentale abstraksjon (som var) laget av glatte, metalliske 'ikke-objekter' ...

'Helion's monumental abstraction (which was) made of smooth, metallic 'non-objects' ...'

In their comprehensive survey of Norwegian grammar, Faarlund et al. $(1997,472)$ present a few examples of the present participle acting as a postmodifier in Norwegian noun phrases, one of them being:

(2) De kristne overleveringene, omfattende mer enn $2 / 3$ av alle verdens kristne ...

'The Christian remnants, comprising more than two-thirds of all the world's Christians ...'

This construction seems distinctly marginal in present-day Norwegian.

In this article we shall try to gain an impression of how common the various types of clausal modifiers are in English vs. Norwegian noun phrases, and of correspondences between the two languages. We shall do so by first looking at some POS-grams based on the British National Corpus (BNC), which will give an idea of the frequencies of some of the English modifier types at the focus of our attention, in comparison with other modifiers (Section [2]). Then, in Section [3], we shall discuss modifier types in terms of their degree of explicitness and formulate our main research questions. Section [4] will present the material investigated for this study, viz. the English-Norwegian Parallel Corpus (ENPC) and the Multiple-translation Corpus, both part of the Oslo Multilingual Corpus. The modifier types analysed in the ENPC will be set out in Section [5], followed by a 
more detailed discussion of the recorded English-Norwegian correspondences in Section [6]. Results from the Multiple-translation Corpus will be set out in Section [7], before our Conclusion is presented in Section [8].

[2] INFORMATION FROM POS-GRAMS

The frequencies of different phrase structures can now be studied by means of POS-grams, which are sequences of items from particular parts of speech, or word classes. Table 2 on the facing page gives the figures for the most frequent 3-POSgrams in the British National Corpus consisting of any determiner in the first slot and any noun in the second slot, and with the third slot open. The figures are taken from the website 'Phrases in English'. ${ }^{3}$ The tags which are of the most interest to us are: ${ }^{4}$

- AT0: the articles (the, $a$, an and also no)

- CJC: co-ordinating conjunction (and, or, but)

- CJT: the subordinating conjunction that (whether acting as a relative pronoun or a conjunction in nominal clauses)

- DPS: possessive determiner

- NN1: singular common noun

- NN2: plural common noun

- NN0: common noun, neutral for number (committee, data)

- PRF: the preposition of

- PRP: any other preposition

- TO0: the infinitive marker to

- VBG: the -ing form of the verb BE

- VBN: the past participle of the verb $\mathrm{BE}$

- VHG: the -ing form of the verb HAVE

- VHN: the past participle of the verb HAVE

- VVG: the -ing form of lexical verbs

- VVN: the past participle of lexical verbs

The high frequency of the tag for the infinitive marker to (in Table 2) can be taken to mean that nouns taking infinitive clauses as postmodifiers make up a

[3] This website is available at http://phrasesinenglish.org/.

[4] A complete list of the POS tags used for the BNC are given on the Phrases in English website: http:

//phrasesinenglish.org/POScodes.html. 
TABLE 2: 3-POS-grams in the BNC with any determiner + any noun + open slot. In order of decreasing frequencies of tokens.

\begin{tabular}{lrr} 
3-POS-grams & Types & Tokens \\
\hline AT0 NN1 PRF & 11,969 & $1,027,715$ \\
AT0 NN1 PRP & 30,247 & 452,935 \\
AT0 NN1 NN1 & 29,597 & 280,948 \\
AT0 NN1 CJC & 11,079 & 180,735 \\
AT0 NN2 PRF & 2,969 & 133,245 \\
AT0 NN1 VBZ & 5,268 & 100,159 \\
AT0 NN1 POS & 2,561 & 93,597 \\
AT0 NN1 TO0 & 3,457 & 90,022 \\
AT0 NN1 CJT & 2,920 & 80,465 \\
DPS NN1 PRP & 7,445 & 76,598 \\
AT0 NN1 VBD & 4,375 & 76,068 \\
AT0 NN1 VM0 & 6,783 & 62,606 \\
AT0 NN2 PRP & 5,258 & 52,829 \\
\hline
\end{tabular}

fairly common noun-phrase type, although, obviously, other sequences where nouns are followed by the infinitive marker will also be covered by this POS-gram, such as I left the meeting to spend the evening by myself, where the infinitive clause must be analysed as an independent adverbial. 'CJC' in the final slot (line 4 of Table 2) will capture noun phrases headed by co-ordinate nouns, whereas 'CJT' will include a large number of relative clauses, and also appositional that clauses.

Constructions with postmodifying -ing or past-participle verbs are not numerous enough to be included in Table 2. Table 3 on the next page, however, setting out the frequencies of 2-POS-grams with any noun + past participle or -ing verbs, shows that those combinations are both quite numerous when the preceding slot is not specified, and suggests that past-participle clauses are somewhat more numerous than -ing clauses as postmodifiers of nouns.Table 2 and Table 3 confirm that in addition to prepositional phrases various types of clausal modifiers account for a substantial proportion of English noun phrases. On the whole the POSgrams from the BNC tally well with the results reported by Quirk et al. (1985) and Biber et al. (1999), with the possible qualification that the proportion of postmodifying infinitive clauses in Biber et al. may seem to be surprisingly low compared with our own POS-gram findings. It should be borne in mind that these results are not directly comparable, since the POS-grams do not represent the various nounphrase structures directly (and are not divided into text categories); also, Quirk et al. include noun phrases headed by both pronouns and proper names, while the POS-grams set out in Table 2 and Table 3 only include cases with common nouns as heads. 
TABLE 3: 2-POS-grams in the BNC with any noun + past participle / -ing form of verb. In order of decreasing frequencies of tokens.

\begin{tabular}{lrr} 
2-POS-grams & Types & Tokens \\
\hline NN1 VVN & 9,290 & 68,602 \\
NN2 VVN & 6,546 & 48,121 \\
NN0 VVN & 454 & 3,878 \\
NN1 VBN & 88 & 716 \\
NN1 VDN & 53 & 1,168 \\
NN2 VBN & 24 & 233 \\
$\ldots \ldots \ldots \ldots . .$. & $\ldots \ldots \ldots .$. & $\ldots \ldots .$. \\
NN1 VVG & 6,790 & 45,402 \\
NN2 VVG & 4,248 & 28,831 \\
NN1 VBG & 924 & 7,815 \\
NN2 VBG & 538 & 4,209 \\
NN0 VVG & 410 & 5,302 \\
NP0 VVG & 185 & 833 \\
NN1 VHG & 171 & 947 \\
NN2 VHG & 101 & 541 \\
NN1 VDG & 57 & 379 \\
NP0 VBG & 44 & 181 \\
NN2 VDG & 25 & 186 \\
\hline
\end{tabular}

\section{[3] DEGREES OF EXPLICITNESS, RESEARCH QUESTIONS}

As discussed by Quirk et al. $(1985,1243)$, noun-phrase postmodifiers differ in terms of explicitness. Generally, full finite relative (or appositional) clauses represent a high degree of explicitness, non-finite clauses, often with subjects and/or other clause elements omitted, represent a lower degree, while prepositional phrases and adjective phrases can be said to represent the lowest degree on such a scale. This may be exemplified by (3), where each pair of brackets adds a degree of explicitness:

(3) the girl (\{who was\} standing) in the corner

The difference between the various versions of this noun phrase is not merely a question of the same information being expressed in different ways. The shorter versions are open to more alternative readings than the full version. Thus the girl standing in the corner, with no finite verb, can correspond to different temporal expressions: the girl who was / is / will be standing in the corner. It may also be seen as open in terms of aspect: the girl who stood or was standing etc. If even the -ing verb is omitted, the remaining noun phrase, the girl in the corner, can also cor- 
respond to more explicit constructions with different lexical verbs: the girl who stood/sat/lay/waited in the corner etc. Hence the various versions of (3) differ not only as more or less explicit expressions of the same semantic content, but also in their specification of that content. Steiner (2005) and others (see e.g. Dirdal (This volume)) employ the term EXPLICITATION to refer to the process of making language more explicit, for example in translation, in which case this may imply that elements of meaning which are only implicit in the original are expressed more explicitly in the translation. ${ }^{5}$ The full, most explicit, version of example (3) above cannot be seen as an explicitation of the shorter versions in this sense, since there are clear differences in the semantic content of the various versions: Information is added rather than simply made more explicit.

Since Norwegian finite-clause modifiers are held often to be used where English would have non-finite clauses, either -ing of past-participle clauses, one may ask if Norwegian noun phrases are characterised by a higher degree of explicitness than English ones. This is a question which will be pursued in the remainder of this article. The choices available in each language can be seen in the light of Doherty's $(2004,2)$ SAP PRINCIPLE: THE STRATEGY OF ATTRIBUTIVE PARSIMONY. Her claim is that the lowest possible category of attribute or modifier will generally be preferred on a scale consisting of ADJECTIVE PHRASE > NOUN PHRASE > PREPOSITIONAL PHRASE > VERB PHRASE > (FINITE) CLAUSE. Doherty applies this principle to a comparison of English and German but it may be equally relevant to a comparison of English and Norwegian. In this article the focus is on the high end of the explicitness scale: finite and non-finite clauses. It remains true that variation options are more limited in Norwegian as compared with English noun phrases as far as clausal modifiers are concerned. An interesting question is therefore what Norwegian does in those cases where the English noun phrase does not have any direct Norwegian equivalent.

The questions put above can thus be specified as the following RESEARCH QUESTIONS:

(Ai) To what extent is the same pattern used when the pattern is available in both languages?

(Aii) What correspondences occur if the pattern of the other language is not available?

An important SUBSIDIARY RESEARCH QUESTION is:

(B) Is there any difference in this respect between original texts, in either English or Norwegian, and texts translated from the other language?

[5] Fabricius-Hansen (1998) is among those who discuss the relationship between original and translated texts from a similar point of view. 
It might be hypothesised that transfer from the source language would lead to a higher degree of noun-phrase explicitness in English texts translated from Norwegian than in original English texts, and conversely to a lower degree of explicitness in Norwegian texts translated from English than in original Norwegian texts.

The relationship between noun phrases in original vs. translated texts may further be seen in the light of claims that there are certain general characteristics which can be associated with translated texts, more particularly that they are sometimes more explicit than original language (see e.g. Johansson (2007, esp. p. 307). In the case of noun-phrase modification, such general differences between original and translated texts would push English and Norwegian translated texts higher up the explicitness scale compared with original texts in each language.

\section{[4] MATERIAL INVESTIGATED}

We shall base our study of some of the most central clausal modifier types occurring in English and Norwegian on the Oslo Multilingual Corpus (OMC), mostly the section called the English-Norwegian Parallel Corpus (ENPC). ${ }^{6}$ As translations can be expected to vary a great deal depending on the individual translator, we shall also consider the recently added Multiple-translation Corpus. This corpus consists of ten different Norwegian translations of each of two original English texts and will give an impression of the kind and extent of variation that can occur in the translation of noun-phrase modifiers from English to Norwegian. ${ }^{7}$

The ENPC is made up of an equal number of English and Norwegian original texts - 30 texts representing Fiction, 20 representing Non-fiction in each case plus their translations into the other language. Table 4 on the facing page illustrates the composition of this corpus, and also gives the number of words making up each of the four sections. ${ }^{8}$

The tagging of this corpus proved to be of limited value in the linguistic analysis for this investigation, one problem being that there is no uniform tag used for relative pronouns, for example. A more general problem is that the tagging is intended to describe items at the level of the individual word, while my focus is on units at the phrase level and above. I therefore concluded that I would have to analyse the actual texts, without the help of the tagging, which in any case does not as yet take in all the sections of the ENPC.

[6] I should like to acknowledge my indebtedness to the people who produced the ENPC, especially our late colleague Stig Johansson.

[7] Johansson (2007) notes some considerable variation among these translations in his Chapters 11 ('Why change the subject?') and 12 ('Sentence openings in English and Norwegian') and comments further on this on p. 307.

[8] From the ENPC manual by Stig Johansson, Jarle Ebeling and Signe Oksefjell, available at this address: http://www.hf .uio.no/ilos/english/services/omc/enpc/ENPCmanual.pdf. 
TABLE 4: Composition of the English-Norwegian Parallel Corpus.

\begin{tabular}{lllll} 
& \multicolumn{2}{c}{ Original texts } & \multicolumn{2}{c}{ Translated texts } \\
\hline & English & Norwegian & English & Norwegian \\
\hline Fiction & 30 & 30 & 30 & 30 \\
Non-fiction & 20 & 20 & 20 & 20 \\
Total texts & 50 & 50 & 50 & 50 \\
Total number of words & 671,700 & 629,900 & 699,400 & 661,500 \\
\hline
\end{tabular}

A further complication was that the otherwise very useful search engine of the ENPC, making it possible to search for matching items - or missing items - in the other language, is based on the s-unit (roughly, sentence). Hence searches for cases where, for instance, Norwegian som (the prevalent Norwegian relative pronoun but also with other common functions) is matched by English which returned a great many irrelevant hits, since many of those occurrences of which would belong to other noun phrases than the one at the focus of my attention. My analysis was therefore based on a word-for-word reading of a random sample consisting of 3 consecutive s-units from each of the 100 texts making up the ENPC (Fiction and Non-fiction, English and Norwegian Originals), with their correspondences in the other language. In putting this sample together I made a point of not including the initial sentence of any text, as it was assumed that they might deviate from non-initial sentences, because of the absence of any preceding context for anaphoric reference.

The ENPC, including my random sample, has the great advantage that a substantial number of different translators are represented, thus reducing the potential impact of individual translator styles. The variation that may occur between different translators will be further addressed in Section [7] below, where the Multiple-translation Corpus will be analysed.

[5] MODIFIER TYPES ANALYSED IN THE ENPC

Noun phrases containing clausal modifiers, in one language or both languages, were subjected to further scrutiny. The analysis included all modifiers with finite or non-finite verbs in them. The random sample was found to contain 104 noun phrases of the kind specified, i.e. noun phrases where a clausal modifier was identifiable in one or both languages.

These turned out to be very unevenly distributed depending on the direction of the translation: As many as 70 were recorded in texts originating in English, 
only 34 in texts originating in Norwegian. ${ }^{9}$ The frequencies recorded of the various noun-phrase structures are set out in Figure 1 and Figure 2.

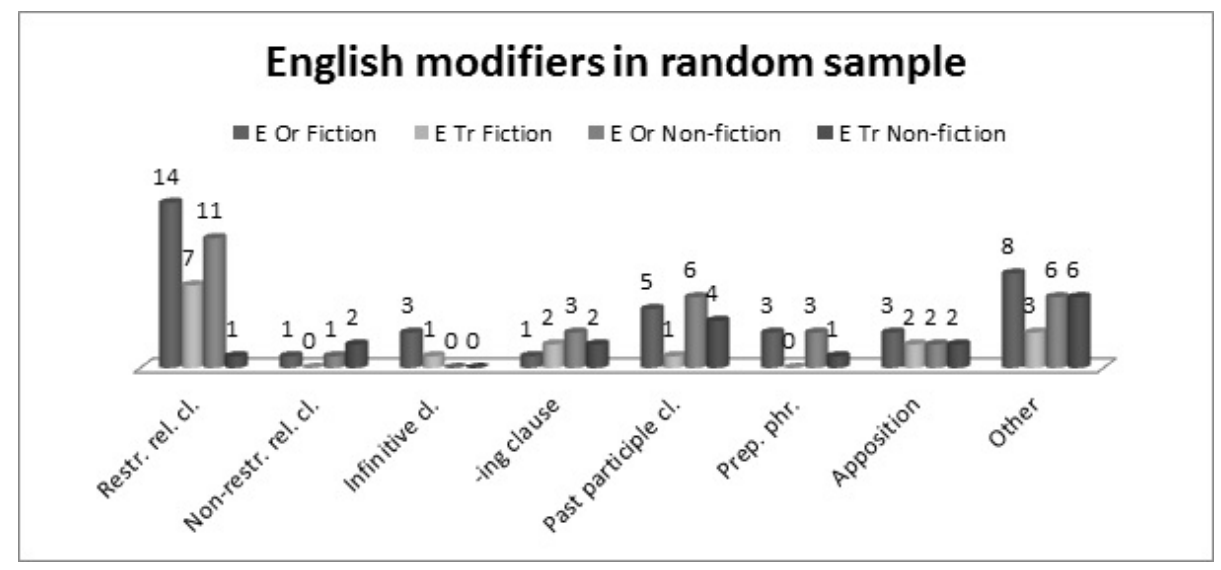

FIGURE 1: English modifiers in random sample from the ENPC: Fiction and Nonfiction, Original and Translated texts.

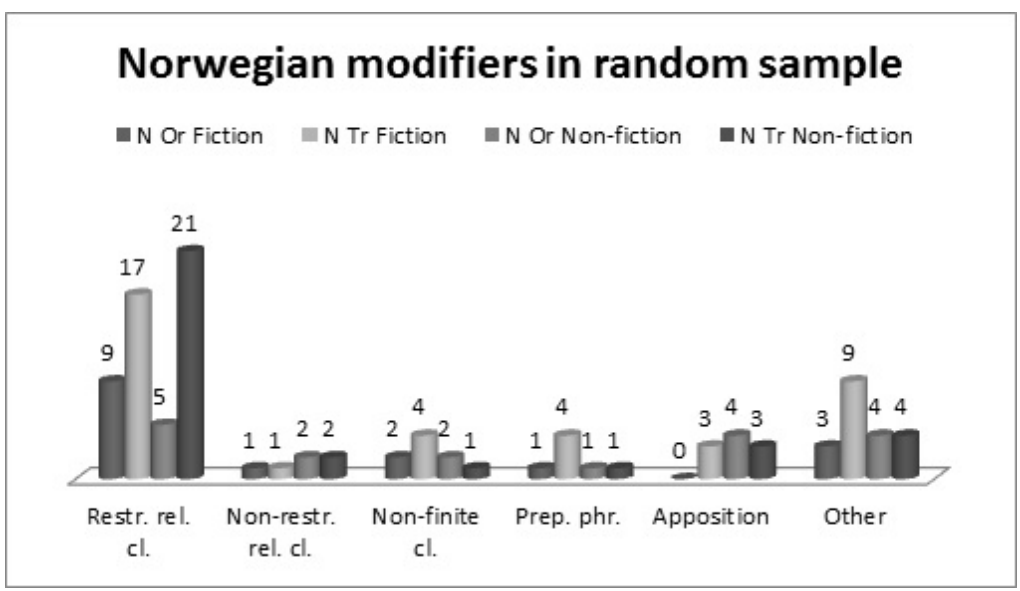

FIGURE 2: Norwegian modifiers in random sample from the ENPC: Fiction and Nonfiction, Original and Translated texts.

It will be seen that some of the structures distinguished are different for the two languages, for the simple reason that the noun-phrase types recorded were very dissimilar in some cases. What forms the recorded NPs took in the two languages will be illustrated by the examples to be presented below.

[9] If this distribution is compared with an even distribution, i.e. one with 52 noun phrases in each original language, the Chi-square test applied to the resulting $2 \times 2$ table shows the recorded difference to be statistically significant at the 5 per cent level $\left(\chi^{2}=5.7293\right)$. 
The strong overall tendency for clausal modifiers to be more frequent in texts originating in English can be seen to hold in both languages for all the most numerous noun-phrase structures distinguished, where results are the most reliable. In the case of the most common modifier type, restrictive relative clauses, the English figures are exactly twice as high for Original Fiction as for Translated Fiction, while for Non-fiction the ratio is as high as 11 to 1 . This is reflected on the Norwegian side by restrictive relative clauses, again the most common modifier type, being much more frequent in texts translated from English than in Original Norwegian texts, in both Fiction and Non-fiction.

A more predictable result is that there is a wider spread of modifier types in the English material. Relative clauses predominate even more in the Norwegian texts: Of the 104 modifiers recorded, restrictive relative clauses account for 33 cases in the English texts (Original and Translated), as many as 52 in the Norwegian correspondences. If the much smaller numbers of non-restrictive relative clauses are added, relative clauses combined make up 58 of the 104 Norwegian modifiers ( 56 per cent), as against a more modest 37 (36 per cent) in the English material. ${ }^{10}$ As expected, the English texts instead contain a larger proportion of non-finite clauses, most notably -ing clauses and past-participle clauses. Most of the Norwegian constructions appearing as non-finite clauses in Figure 2 are infinitive clauses, but there are also a few past-participle clauses, as will be shown below.

It may also be noted that the proportion of clausal modifiers counted in Nonfictional texts is higher than what an even distribution between Fiction and Nonfiction would lead one to expect: The number of Fictional texts in the ENPC is 50 per cent higher than that of Non-fiction ( $30 \mathrm{vs.} 20$ texts in each Original language; see above, Table 4), but the distribution of modifiers is much more even: 38 against 32 for English Original texts, 16 against 18 for Norwegian Original texts. This indicates that in the ENPC noun phrases displaying this type of complexity are more common in Non-fiction than in Fiction, which may be seen as a reflection of a more formal style in many of the Non-fictional texts. ${ }^{11}$

We shall take a closer look at correspondences between English and Norwegian modifiers below, but first we shall consider some of the noun phrases with clausal modifiers which were recorded. We start with a few examples from Fictional texts where the English version is the Original. The Original version will in-

[10] According to the Chi-square test this difference is statistically significant at the 1 per cent level $\left(\chi^{2}=\right.$ 7.7503).

[11] This may further be connected with the fact that fictional texts typically contain a large proportion of direct speech. Biber et al. (1999, esp. p. 578) found that noun phrases with complex modification structures are particularly frequent in their News and Academic prose categories, and the least frequent in Conversation. 
variably be given first, followed by the Translation..$^{12}$ The focused noun phrases, or part of them, will appear in bold. ${ }^{13}$

(4) They think I'm lucky to have a friend like Oliver. Oliver impresses people. He talks well, he's travelled to distant lands, he speaks foreign languages, he's conversant with the arts - more than conversant - and he dresses in clothes which don't fit the contours of his body and are therefore declared to be fashionable by people in the know. All of which isn't like me. [JB1/English Original Fiction]

De synes jeg er heldig som har en venn som Oliver. Oliver gjør inntrykk på folk. Han kan uttrykke seg, han har reist til fjerne land, han snakker fremmede språk, han er bevandret i kunstens verden - mer enn bevandret - og han kler seg i plagg som ikke passer til kroppens konturer, og blir derfor ansett for å være moderne av folk som har greie på det ['people who have knowledge of it']. ${ }^{14}$ Selv er jeg helt annerledes. [JB1T]

In (4) we can see that the noun phrase in the English Original text takes a postmodifying prepositional phrase, in the know, which must be considered a set phrase. No corresponding prepositional expression seems to exist in Norwegian, and the Norwegian Translation instead has the predominant modifier type, the (restrictive) relative clause som har greie på det ['who have knowledge of it'].

Another instance where a Norwegian relative clause is used to translate a postmodifying prepositional phrase in English is seen in (5):

(5) The only eyes that stared at him were in the plaster mannequins. They looked out, day and night, as if they dreamed the street, and all the passersby were figments in the glass. Who can resist the privacy of crowds? [JC1/English Original Fiction]

De eneste øynene som stirret på ham befant seg på utstillingsdukkene. De sto og så ut, dag og natt, som om de drømte at gata og alle forbipasserende var fantasifostre i glasset. Hvem kan motstå den privatlivets fred man kan nyte i en menneskemengde ['that private life's peace one can enjoy in a human-crowd']? [JC1T]

This example confirms the impression we have already gained of English noun phrases tending to have a more compact information structure than Norwegian

[12] Original and Translated texts can easily be distinguished by the ' $T$ ' which consistently appears as the final element in the codes of Translated texts.

[13] For a complete list of the texts making up the ENPC and the codes representing each text, see http: //www.hf.uio.no/ilos/english/services/omc/enpc/ENPCfiction.html (for fiction) and http: //www.hf .uio.no/ilos/english/services/omc/enpc/ENPCnon.html(non-fiction).

[14] With this and subsequent Norwegian examples literal translations of focused elements are provided in square brackets. 
ones. Even with the zero relative pronoun the Norwegian postmodifier consists of six words, man kan nyte i en menneskemengde ['one can enjoy in a human-crowd'], corresponding to the two words of the English postmodifier, and yet the information load seems to be much the same in the two languages: The translator cannot really be said to have added any significant information which cannot also be read out of the English text, but then the wider context contributes to that reading in addition to the noun phrase itself, especially the fact that the noun phrase we are focusing upon occurs as the object of the verb resist, which can be said to invite a reading with nyte ['enjoy'] in the object noun phrase - one resists (or otherwise) something that can be enjoyed. Thus this can be seen as a pretty clear instance of explicitation (cf. our reference to Steiner (2005) in Section [3] above).

The next example, again from the section of English Original Fiction, contains several noun phrases with clausal modifiers:

(6) The Senator was the person to begin with, for he was Francis Chegwidden Cornish's grandfather, and the origin of the wealth that supported Francis's life until he gained a mysterious fortune of his own.

[RDA1/English Original Fiction]

Senatoren er den rette person å begynne med ['the right person to begin with'], for han var Francis Chegwidden Cornish' bestefar, og kilden til den rikdom som gav Francis det han trengte ['the wealth which gave Francis that (which) he needed'] til han på en så mystisk måte skaffet seg sin egen formue. [RDA1T]

We first notice that the infinitive clause acting as a postmodifier in the first line of the English Original text, to begin with, is translated by a closely similar construction in the Norwegian text, a begynne med. There is a noteworthy difference, however, in that the Norwegian noun phrase also has a premodifying adjective, rette ['right'], which is closely linked to the postmodifying infinitive clause: It is right to begin with the senator, one should begin with the senator (with should appearing in its obligation sense). There can thus be said to be a modal overtone to the meaning of this noun phrase. ${ }^{15}$

The next noun phrase counted in example (6) is the wealth that supported ..., a straightforward restrictive relative clause with the relative that, translated by an equally straightforward relative clause with som in Norwegian, den rikdom som gav .... The Norwegian text then has a short relative clause with the zero relative pronoun, det [zero] han trengte ... ['that (which) he needed']. This is a translation which is part of a slight re-writing of the English Original text, gav Francis det han trengte ['gave Francis what he needed'], corresponding to supported Francis' life in

[15] Perhaps especially in informal (often colloquial) style even Norwegian may express this kind of meaning without any premodifying adjective: Han er mannen å snakke med ['He's the man to talk to']. 
the Original. Again this can be seen as a case of English using a more compact information structure than Norwegian, or as another instance of explicitation, i.e. the same information is being expressed.

In example (7) the English Original text has a typical past-participle clause acting as the postmodifier of organization:

(7) It was her job; she was the representative of an international human rights organization sent to monitor political detentions and trials, and to assist people like my father and their families.

[NG1/English Original Fiction]

Det var jobben hennes; hun representerte en internasjonal menneskerettsorganisasjon som skulle overvåke politiske arrestasjoner og rettssaker og støtte slike mennesker som min far og deres familier ['human rights organisation which was to supervise political arrests and court cases and support such people as my father and their families']. [NG1T]

It can be seen that this past-participle clause contains two infinitive clauses, each with an adverbial function, within itself. In the Norwegian Translation this complex structure is again rendered by a finite relative clause, in this case with two co-ordinated predicates.

The next example is from the Non-fictional section of the ENPC, again with English as the Original language:

(8) This was the environment in which Henry Miller grew up, and which left its mark on practically every page of writing he ever produced. It was a threateningly unstable world; but for a boy with a curious and receptive mind it was also a rich, exciting and even mysterious place in which to grow up. [RF1/English Original Non-fiction]

Det var dette miljøet Henry Miller vokste opp i ['It was this environment Henry Miller grew up in'], og som satte sitt preg på ['which left its mark om'] så å si hver eneste side han noen gang skrev ['every single page he ever wrote']. Det var en skremmende ustabil verden; men for en gutt med et vitelystent og mottagelig sinn var det også et rikt, spennende og til og med hemmelighetsfullt sted å vokse opp ['place to grow up']. [RF1T]

In (8) the first three clausal modifiers are straightforward relative clauses in the English Original, and rendered as such even in the Norwegian Translation. We may note that the first of these relative clauses begins with a prepositional phrase with the relative pronoun acting as prepositional complement: in which Henry Miller grew up. This is a fairly common construction in English, and by no means as stylistically marked as the same construction would be in Norwegian: $i$ hvilken Henry Miller vokste opp is a possible construction, but very formal in present-day 
Norwegian. Instead the translator opts for the standard variant in present-day Norwegian, splitting the prepositional phrase so that the preposition ends up in final position in the relative clause, while the relative pronoun can only come in initial position, although in this case the zero relative pronoun is selected. Moreover, the third relative clause - he ever produced / han noen gang skrev - has the zero relative pronoun in both languages.

The prepositional phrase acting as a postmodifier in the italicised noun phrase in (8) - a boy with a curious and receptive mind / en gutt med et vitelystent og mottagelig sinn - may be noted as a non-verbal modifier which could easily be replaced by a straightforward finite relative clause in either language: who had a curious and receptive mind / som hadde et vitelystent og mottagelig sinn. These prepositional phrases could be seen as clear clausal equivalents but were not included in my counts, which only comprised constructions appearing as clausal modifiers in at least one of the two languages.

The final modifier in example (8) is also noteworthy, as this is an example of the rather special infinitive relative clause type which occurs in English with the relative pronoun acting as prepositional complement (and no possibility of splitting up the prepositional phrase) (cf. Table 1, second row from the bottom). This pattern does not exist in Norwegian, and the translator instead uses a straightforward infinitive clause as postmodifier, although it may be noted that the preposition is omitted. If inserted, it would take the form of på: et sted å vokse opp på ['a place to grow up at'].

Example (9) is from Fiction, this time with Norwegian as the Original language:

(9) Det er ikke akkurat Hermans livrett. Han spekulerer alltid på hvor restene egentlig kommer fra, for han kan ikke huske å ha spist noe som ligner på ['anything which resembles'] restene hverken lørdagen eller søndagen, og Herman har en guffen mistanke om at det er ålen til faren som er smuglet ['a nasty suspicion about that it is the eels of the Father that are smuggled ...'] inn i den mystiske gratengen.

[LSC1/Norwegian Original Fiction]

It's not exactly Herman's favorite dish. He always speculates on where the leftovers actually come from because he can't remember having eaten anything resembling the leftovers either Saturday or Sunday, and Herman has a nasty suspicion that Father's eels are smuggled into the mysterious soufflé. [LSC1T]

Two points are illustrated by example (9). For one thing, it has what is a pretty common correspondence pair in my material: a regular relative clause in Norwegian, rendered by a postmodifying -ing clause in English. The fact that the antecedent is an indefinite pronoun, anything, rather than a noun may serve to make the relative-clause option less likely in English (but certainly not impossible: any- 
thing that/which resembles is fully acceptable). One of the reasons for that may be that an indefinite pronoun is a particularly light antecedent, which sits well with a modifying -ing clause, a lighter construction than a finite relative clause.

Secondly, example (9) has what must be taken as a straightforward apposition, with the second element being a (finite) that clause, in the English version: $a$ nasty suspicion that Father's eels are ... . The corresponding construction in the Norwegian Original text begins with a preposition which takes as its prepositional complement a similar nominal clause: en guffen mistanke om at det er ålen til faren som er smuglet ... ['a nasty suspicion about that it is the eels of the Father that are smuggled ...'], although the Norwegian at clause has a cleft construction inside itself. This difference between the two languages is connected with the fact that English that clauses cannot function as prepositional complements, while there is no such constraint on similar clauses in Norwegian. The semantic structures of the two noun phrases are nevertheless closely similar: In both languages the that/at clause expresses the object of the verb underlying the nominalisation suspicion/mistanke.

Example (10) has a parallel postmodifying infinitive clause in both the Norwegian Original text and in its English Translation. Another noteworthy feature of this example is that the Norwegian text (in nynorsk) has a prepositional phase with a compound noun, på gutungevis, which is translated by an English noun with a postmodifying relative clause, the way a young boy does. ${ }^{16}$

(10) Han spring over Spirele, opp tømmervegen, til myra nedanom Ganskebekk. Han spring i rykk og napp, på gutungevis ['in boy's-way']. Det er så mange forunderlege ting å stoppa for ['things to stop for']. Over han steilar kvite hestar av godversskyer mot middagssola.

[KFL1/Norwegian Original Fiction]

He runs across Spirele, up the logging path, to the bogs down near Ganske Creek. He runs in fits and starts, the way a young boy does. There are so many wonderful things to stop for. Above him, white horses of fairweather clouds rear toward the midday sun. [KFL1T]

We have seen that past-participle clauses acting as postmodifiers in noun phrases are more frequent in English than in Norwegian. (11) is a reminder that they occur in both languages, even, as in this case, in a sentence originating in Norwegian. The fact that not only the focused noun phrase but the whole sentence is short and simple may help to make this type of construction less objectionable in Norwegian.

[16] Most of the Norwegian texts in the ENPC are in bokmål, the Norwegian variety spoken by the majority of Norwegians, but two are in nynorsk. The two varieties of Norwegian are not distinguished in the makeup of the corpus, but the information is available in the text headers and the text overview. 
(11) "Jeg har gitt ham vann kokt på urter ['water boilt on herbs']." "Er han skadet?" [SH1/Norwegian Original Fiction]

"I have given him water boiled with herbs." "Is he hurt?" [SH1T]

\section{[6] ENGLISH-NORWEGIAN CORRESPONDENCES IN THE ENPC}

We need to take a closer look at correspondences between the English and the Norwegian modifiers recorded in our random sample from the ENPC. Table 5 sets out the results for constructions originating in English, Table 6 those for constructions originating in Norwegian. Fiction and Non-fiction are merged in these tables, as are some of the less frequent modifier types.

TABLE 5: Correspondences between English Original and Norwegian Translated texts in random sample from the ENPC. Fiction and Non-fiction combined. Sums as percentages of total.

\begin{tabular}{|l|rrrr|r|}
\hline ENG. OR NORW. TR & Relative cl. & Non-finite cl. & Prep. phrase & Other & Sums \\
\hline Relative clause & 20 & 0 & 1 & 6 & $27(38.6 \%)$ \\
Infinitive clause & 0 & 2 & 1 & 0 & $3(4.3 \%)$ \\
-ing clause & 3 & 0 & 0 & 1 & $4(5.7 \%)$ \\
Past pcl. clause & 6 & 3 & 1 & 1 & $11(15.7 \%)$ \\
Prep. phrase & 5 & 0 & 0 & 1 & $6(8.6 \%)$ \\
Other & 7 & 0 & 2 & 10 & $19(27.1 \%)$ \\
\hline Sums & $41(58.6 \%)$ & $5(7.1 \%)$ & $5(7.1 \%)$ & $19(27.1 \%)$ & $70(100 \%)$ \\
\hline
\end{tabular}

TABLE 6: Correspondences between Norwegian Original and English Translated texts in random sample from the ENPC. Fiction and Non-fiction combined. Sums as percentages of total.

\begin{tabular}{|l|rrrr|r|}
\hline ENG. TR NORW. OR & Relative cl. & Non-finite cl. & Prep. phrase & Other & Sums \\
\hline Relative clause & 9 & 0 & 0 & 1 & $10(29.4 \%)$ \\
Infinitive clause & 0 & 1 & 0 & 0 & $1(2.9 \%)$ \\
-ing clause & 3 & 0 & 0 & 1 & $4(11.8 \%)$ \\
Past pcl. clause & 1 & 2 & 1 & 1 & $5(14.7 \%)$ \\
Prep. phrase & 1 & 0 & 0 & 0 & $1(2.9 \%)$ \\
Other & 3 & 1 & 1 & 9 & $13(38.2 \%)$ \\
\hline Sums & $17(50.0 \%)$ & $4(11.8 \%)$ & $2(5.9 \%)$ & $11(32.4 \%)$ & $34(100 \%)$ \\
\hline
\end{tabular}

Individual frequencies are low in most cases, and the recorded distributions should be read with appropriate caution. It can be seen that the most striking difference remains that between the sums total for each direction of translation, already noted: Slightly more than twice as many clause-modified noun phrases, in one language or both languages, were recorded in translations from English into Norwegian as in translations from Norwegian into English. Hence individual frequencies can also be expected to be lower for the latter than for the former 
direction of translation, which they are in most cases. If one focuses on the relative distributions, expressed as percentages for the sums appearing in Table 5 and Table 6, there is indeed a remarkable similarity between the two tables: In both English and Norwegian the distribution between the various modifier types distinguished is largely the same whether noun phrases were recorded from Original or from Translated texts. It is true that the percentages vary quite a bit between Table 5 and Table 6, but not by much more than can be expected because of the low raw frequencies. ${ }^{17}$ There is no clear tendency in this (admittedly limited) material for translated constructions to be longer or more explicit than those in original texts, as has sometimes been found in other investigations. ${ }^{18}$

One noteworthy, and consistent, difference is that between English and Norwegian as regards the proportion of relative clauses: We have already seen that this modifier type is distinctly more frequent in Norwegian than in English, and that this is true of both Original and Translated texts for both languages, a difference which is statistically significant.

Another noteworthy result emerging from Table 5 and Table 6 is that concerning the two typically English modifier types: -ing clauses and past-participle clauses. It might have been expected that these modifier types would be more frequent in English Original texts than in Translated ones, but those expectations are not borne out by our results. Indeed, in relative terms -ing clauses are more frequent in Translated texts (11.8 as against 5.7 per cent), but then the raw frequencies are very low. Three of the four -ing clauses correspond with Norwegian relative clauses in each case.

As for past-participle clauses, their proportions of all the English modifier types distinguished are very close: 15.7 per cent for English Original texts, 14.7 per cent for English Translations.

If we look for the big picture, the tendency is confirmed for English noun phrases to be characterised by a more compact information structure than Norwegian ones. Constructions where the meaning expressed by a noun-phrase modifier in one language is expressed outside that noun phrase in the other language can often be seen as the extreme case of explicitation. If such cases are added to the explicitness scale suggested in Section [3] above, this scale would look like this, from high to low:

MODIFICATION EXPRESSED OUTSIDE SAME NOUN PHRASE > FINITE CLAUSE AS MODIFIER > NON-FINITE CLAUSE AS MODIFIER > VERBLESS CLAUSE AS MODIFIER $>$ NON-CLAUSAL MODIFIER ${ }^{19}$

[17] The underlying material reveals some tendency for translations to be freer in Fiction than in Non-fiction but this tendency is not sufficient to warrant any firm conclusion.

[18] See Johansson (2007).

[19] E.g. adjective phrases and prepositional phrases. 
The fact that clausal modifiers combined have been found to be distinctly less frequent in texts with a Norwegian origin is noteworthy also from the point of view of explicitness. On the assumption that on the whole writers in the two languages will tend to express the same kinds of meanings, this result can mean (i) that Norwegian more often expresses similar meanings by less explicit, nonverbal modifiers, such as adjective phrases and prepositional phrases; and/or (ii) that Norwegian more often expresses similar meanings outside the same noun phrase, representing a contrary tendency towards a higher level of explicitness. The results set out in Table 5 and Table 6 do not reveal any clear tendency of type (i), but then it should be borne in mind that noun phrases with non-clausal modifiers in both languages were not included in my counts, and in this particular respect there seems to be a great deal of transfer from source to target language, since the figures for both English and Norwegian do vary considerably between Original and Translated texts.

On the other hand, some of the examples already considered, most notably (5) and (7), do illustrate the latter tendency distinguished above, type (ii), the meaning of the English clausal modifier being expressed outside the same noun phrase in the Norwegian correspondence. We shall look for further evidence in some more examples from our random sample from the ENPC.

Like quite a few of the other examples we have considered, (12) contains a correspondence pair which definitely places Norwegian higher up the explicitness scale than the English expression: English has a simple adjective, lovable, where the Norwegian translation has an indefinite pronoun, noe, followed by a relative clause, som må elskes ['something which must be loved']. The same is true of the focused noun phrase in (13), with a postmodifying prepositional phrase in English. In the Norwegian translation this prepositional phrase has the function of an adverbial, separate from the subject noun phrase: En mann kom på ski ... ['A man came on skis ... '].

(12) It is edible, lovable, or lethal. Life as an object of scientific inquiry requiring precise definition is much more difficult. Even scientists, who are notorious for their indecent curiosity, shy away from defining life. [JL1/English Original Non-fiction]

Det er noe dødelig, spiselig eller noe som må elskes ['something which must be loved']. Det er langt mer vanskelig når livet blir objekt for en vitenskapelig undersøkelse som forutsetter en presis definisjon. Selv vitenskapsmennene, som er beryktet for sin uanstendige nysgjerrighet, viker unna for å definere livet. [JL1T]

(13) A man on skis appeared from the direction of the Mairie and, with marvellous inevitability, collided with the only other owner of assisted transport, a man on an ancient sled. [PM1/English Original Non-fiction] 
En mann kom på ski fra rådhuset ['A man came on skis from the Mairie'], og greide utrolig nok å støte sammen med den eneste som også benyttet et transportmiddel, en mann på en gammeldags kjelke. [PM1T]

Example (14) likewise has a correspondence pair where the Norwegian version places itself higher up the explicitness scale, with a postmodifying adjective phrase (which could alternatively be analysed as a past participle) in the English Original translated into a Norwegian relative clause:

(14) On some of the billions of planets in the Milky Way Galaxy, life may never arise. On others, it may arise and die out, or never evolve beyond its simplest forms. And on some small fraction of worlds there may develop intelligences and civilizations more advanced than our own.

[CSA1/English Original Non-fiction]

På noen av de mange milliarder planeter i Melkeveisystemet vil det muligens aldri oppstå liv. På andre kan liv oppstå og dø ut igjen - eller kanskje livet aldri utvikler seg lenger enn til de aller enkleste former. Og på en ørliten del av alle disse verdenene kan det utvikle seg intelligenser og sivilisasjoner som er mer avanserte enn vår egen ['intelligences and civilisations which are more advanced than our own']. [CSA1T]

This difference is also demonstrated very clearly by example (15), with a relative clause in the Norwegian Original followed by another sentence, corresponding to a past-participle clause and a relative whose clause in the English Translation:

(15) Men også de mange helleristningene gir oss innsikt i perioden. Tegningene på bergflatene viser folk som deltar i religiøse handlinger. Disse ritualene skulle øke fruktbarheten på åkeren, blant dyra og hos menneskene ['... people who participate in religious acts. These rituals should increase the fertility of the field, among the animals and with the human beings']. [ILOS1/Norwegian Original Non-fiction]

Valuable information about the Bronze Age is provided by the mighty burial mounds erected at the time, and by the many rock carvings. These drawings on flat rock surfaces depict people engaged in religious rituals whose purpose was to make fields, animals and humans more fruitful. The Iron Age (500 B.C.-A.D. 800) [ILOS1T]

(15) illustrates what was taken as the high point of our explicitness scale, part of the meaning of the modifying structure of the English noun phrase being expressed in a sentence separate from that noun phrase in the Norwegian Original text.

In the final example we shall consider there are two cases of Norwegian placing itself higher up the explicitness scale than its English correspondence: Nor- 
wegian first has a relative clause modifying the head noun, utgravningene som er foretatt ..., where English has a postmodifying prepositional phrase, excavations of ... (where the following prepositional complement expresses the object of the verb underlying the nominalisation excavations) ; then Norwegian has a past-participle clause, gjort med moderne metoder ..., which in part corresponds with a premodifying adjective, modern, in the English Translation:

(16) De arkeologiske utgravningene som er foretatt i den eldste bykjernen i de siste tiår ['the excavations which are (=have been) carried out in the oldest city nucleus in the past decades'], taler ikke mot sagaens datering, heller tvertimot: Dateringer gjort med moderne metoder ['Datings done with modern methods'] (radiokarbondateringer, dendrokronologi) tyder på at noe avgjørende skjedde her omkring eller kort før år 1000. [JS1/Norwegian Original Non-fiction]

The archaeological excavations of the oldest part of the city centre in the past decades do not contradict the dates of the sagas. In fact, modern methods of dating (radiocarbon, dendrochronology) indicate that something important happened here just before or around the year 1000. [JS1T]

We have seen, both from the tables and from the examples presented above, that our random sample from ENPC contains a considerable number of noun phrases where the Norwegian version places itself higher up what we are calling the explicitness scale than its English correspondence. The corpus also contains cases of the opposite distribution, but higher explicitness in Norwegian is definitely the prevailing tendency.

\section{[7] THE MULTIPLE-TRANSLATION CORPUS}

We have noted that translation involves a great deal of variation. As an illustration we shall turn to the Multiple-translation Corpus, which is an addition to the ENPC. It consists of two Original English texts, each translated into Norwegian by ten professional translators (different ones for the two texts). One text is Fictional: the short story 'A Lamia in the Cevennes' by A. S. Byatt. The other text is Non-fictional: the scientific article 'Communication and cooperation in early infancy: a description of primary intersubjectivity' by Colwyn Trevarthen.

This corpus offers an excellent opportunity to study alternative translation strategies employed by professional translators. ${ }^{20}$ We shall consider one sentence from each of the two English texts and their alternative translations into Norwegian. (17) is from the scientific article by Trevarthen. The English Original sentence is given first, followed by the ten translations:

[20] See e.g. the contributions by Behrens (This volume) and Dirdal (This volume). 
(17) They react as agents who are subordinate to acts of babies. [Multiple-translation Corpus/Trevarthen]

a. De reagerer som opphav som er underordnet spedbarnets handlinger. 'They react as/like parents who are subordinated (to) the baby's acts.'

b. De reagerer som om de er underlagt babyens handlinger.

'They react as if they are subordinated (to) the baby's acts.'

c. De reagerer som om de underordner seg det barna gjør.

'They react as if they subordinate themselves (to) what the children do.'

d. De reagerer som representanter som er underordnet babyenes handlinger.

'They react as/like representatives who are subordinated (to) the babys' acts.'

e. De reagerer som agenter som er underlagt handlingene til den lille. 'They react as/like agents who are subordinated (to) the acts of the little (one).'

f. De reagerer som agenter som er underordnet det babyen foretar seg. 'They react as/like agents who are subordinated (to) what the baby does.' g. De reagerer som formidlere som er underordnet spedbarns handlinger. 'They react as/like mediators who are subordinated (to) babys' acts.'

h. Hun reagerer som en mellommann underordnet barnets handlinger. 'She reacts as/like an intermediary subordinated (to) the child's acts.'

i. Hun reagerer som en aktør som underordner seg spedbarnets handlinger.

'She reacts as/like a participant who subordinates herself (to) the baby's acts.'

j. De reagerer som representanter som er underordnet babyenes handlinger.

'They react as/like representatives who are subordinated (to) the babies' acts.'

(17) is a sentence with a straightforward finite relative clause acting as a postmodifier of agents, with the relative who expressing animate reference. In this case the same construction is available in the Norwegian target language, with relative som, and one might think that this would be the obvious translation. And yet it can be seen that as many as three of the ten translators - those suggesting (17b), (17c) and (17h) - chose a different solution.

A reason for that may be that the as preceding agents in the English sentence is naturally translated as Norwegian som, and in fact all the ten translators have reagerer som. It might be considered stylistically clumsy to have two occurrences of som within the space of a few words in the translated sentence. No obvious alternative to the Norwegian relative pronoun som seems to be possible here, the 
zero relative pronoun being unavailable in subject function. A wish to avoid such stylistic clumsiness may have motivated the three translators who chose a different solution, avoiding the relative clause in their Norwegian renderings. One of them, (17h), instead used a postmodifier which is much less common in Norwegian, a past-participle clause. (17b) and (17c), on the other hand, preferred translations [literally, 'react as if'] which also steered clear of another problem in this sentence, the rendering of English agents. The most direct Norwegian equivalent, the cognate noun agenter, does not seem like a very good choice in this context; even more than its English equivalent, the Norwegian noun conjures up images of the secret agents of the intelligence world, and only two translators, (17e) and (17f), have that. A number of alternatives are used by the others: opphav, representanter, formidlere, mellommann og aktør, confirming that this is a small translation challenge in itself. It may also serve as a useful reminder that lexical and stylistic considerations may have an impact on the syntactic patterns chosen in translations.

In terms of explicitness, even the English sentence represents a high level in this case, with a finite relative clause. All but one of the Norwegian translations similarly employ finite clauses, although not all of them relative. The exception is (17h), which has a past-participle clause.

The other sentence we shall look at from the Multiple-translation Corpus is from the short story by Byatt:

(18) It was not a boring rectangular pool, but an irregular oval triangle, hugging the contour of the terrace on which it lay. [Multiple-translation Corpus/Byatt]

a. Det var ikke et kjedelig, firkantet basseng, men et uregelmessig, ovalt triangel som motsvarte formen på terrassen som det lå på.

'It was not a boring, rectangular pool, but an irregular, oval triangle which corresponded (to) the shape of the terrace which it lay on.'

b. Det var ikke noe kjedelig firkantet basseng, det var en ujevn, nærmest trekantet oval som fulgte terrassens form.

'It was not any boring rectangular pool, it was an uneven, almost triangular oval which hugged the terrace's form.'

c. Bassenget var ikke kjedelig og rektangulært, det var en uregelmessig trekant som fulgte terrassens konturer.

'The pool was not boring and rectangular, it was an irregular triangle which hugged the terrace's contours.'

d. Det var ikke et kjedelig firkantet basseng, men en uregelmessig oval trekant som fulgte omkretsen av terrassen det lå på. [With the zero relative pronoun]

'It was not a boring rectangular pool, but an irregular oval triangle which 
hugged the rim of the terrace it lay on.'

e. Det var ikke noe kjedelig, firkantet basseng, men et uregelmessig, ovalt triangel som favnet hele terrassens omkrets.

'It was not any boring, rectangular pool, but an irregular, oval triangle which embraced the whole terrace's rim.'

f. Det var ikke noe kjedelig, rektangulært basseng, men en uregelmessig, oval triangel som fulgte konturene av avsatsen det lå på. [With the zero relative pronoun]

'It was not any boring, rectangular pool, but an irregular, oval triangle which hugged the contours of the terrace it lay on.'

g. Det var ikke noe vanlig svømmebasseng, kjedelig og firkantet, men et slags uregelmessig ovalt triangel som fulgte konturene av terrassen ... . 'It was not any ordinary pool, boring and rectangular, but a kind (of) irregular oval triangle which hugged the contours of the terrace.'

h. Det var ikke et kjedelig, rektangulært basseng, men et uregelmessig ovalt triangel, som fulgte konturene av terrassen det lå på. [With the zero relative pronoun]

'It was not a boring, rectangular pool, but an irregular oval triangle, which hugged the contours of the terrace it lay on.'

i. Det var ikke et kjedelig rektangulært svømmebasseng, men en uregelmessig oval trekant som smøg seg langs konturen av terrassen bassenget lå på. [With the zero relative pronoun]

'It was not a boring rectangular pool, but an irregular oval triangle which wound itself along the contours of the terrace the pool lay on.'

j. Det var ikke et kjedelig, firkantet basseng, men en uregelmessig, oval trekant som fulgte konturen av terrassen det var anlagt på. [With the zero relative pronoun]

'It was not a boring, rectangular pool, but an irregular, oval triangle which hugged the contours of the terrace it was placed on.'

(18) presents the translator with a couple of obvious translation problems: It has a postmodifying -ing clause, with hugging, and it has a relative clause where the relative pronoun acts as a prepositional complement and is immediately preceded by the preposition, on which. As has been noted, -ing clauses have no real equivalent in Norwegian, and in Norwegian relative clauses with the relative pronoun functioning as a prepositional complement the prepositional phrase is usually split up, since neither som nor the zero relative pronoun can occur after the preposition. ${ }^{21}$ It is of great interest to see how various translators handle these problems.

[21] The relative pronoun hvilken (neuter hvilket) is different in that it can occur after the preposition in a prepositional phrase (like English which and whom), but that relative pronoun must now be considered dated. 
As regards the sequence of preposition plus relative pronoun in the English Original sentence (on which), it can be seen that as many as six of the ten translators - (18a), (18d), (18f), (18h), (18i) and (18j) - solve the problem by splitting up the prepositional phrase, all but one of them selecting the zero relative pronoun. (18a) instead uses som. The others - (18b), (18c), (18e) and (18g) - seem to regard the relative clause on which it lay as semantically redundant and simply leave it out, being content to translate only the contour of the terrace, one - (18g) - choosing a prepositional phrase with the preposition av, the closest Norwegian equivalent of of, the others using an -s genitive.

As for the translation of the English -ing clause, there is much less variation than might have been expected. In fact all ten translators render this construction by means of a straightforward Norwegian relative clause with the relative pronoun som, the only possible relative pronoun in this subject function. This can be seen as another instance of the Norwegian version being more explicit than its English correspondence. It should be noted, however, that in this case four of the ten translations also display the opposite relationship in leaving the relative clause on which it lay untranslated.

The two sentences we have considered from the Multiple-translation Corpus demonstrate some of the great variation that occurs even in translations carried out by professional translators. We have seen that a number of factors - not only syntactic but also stylistic and lexical ones - may be at play in determining the syntactic pattern emerging from the translation process.

\section{[8] CONCLUSION}

We have seen that the modification of noun phrases is open to a great deal of variation, in both English and Norwegian. In the Norwegian case this was confirmed by our examination of two English sentences from the Multiple-translation Corpus and their translations into Norwegian by ten different professional translators.

Our analysis of a random sample from the English-Norwegian Parallel Corpus (ENPC), also part of the Oslo Multilingual Corpus, confirmed that finite clauses acting as modifiers in noun phrases, most of them relative clauses, make up a larger proportion of clausal modifiers in Norwegian, while various types of non-finite modifiers are more common in English. A substantial proportion of Norwegian relative clauses are matched by -ing clauses and past-participle clauses in the corresponding English noun phrases. That is true of both directions of translation and is seen as an indication of a higher level of explicitness in the reference expressed by Norwegian noun phrases, in contradistinction to the more compact information structure of English noun phrases. In many cases the same information seems to be expressed, i.e. the relationship between the Original and the Translation can be seen as an instance of explicitation, as this term is used by 
Steiner (2005) and others. In other cases the more explicit version adds semantic content.

As regards our research question (Ai), 'To what extent is the same pattern used when the pattern is available in both languages?', we have seen (cf. Table 5 and Table 6) that to a large extent the translated text sticks to the same modifier type, but in some cases it does not, and in those cases there is a clear tendency for Norwegian to use a more explicit structure than English, as shown by some of the constructions we have considered.

This impression is confirmed and reinforced when we turn to research question (Aii), 'What correspondences occur if the pattern of the other language is not available?'. In these cases it is typically Norwegian that is the language where patterns are not available, since that language lacks any straightforward equivalent of the English -ing clause in particular; in addition it has been confirmed that pastparticiple clauses at least are much less common in Norwegian. We have found that, as expected, full finite relative clauses are the prevailing modifier type in the Norwegian correspondences of both these English modifier types, which again means that Norwegian uses a more explicit construction.

As regards our subsidiary research question, (B) 'Is there any difference in this respect between original texts, in either English or Norwegian, and texts translated from the other language?', we have not been able to confirm any clear general tendency of this kind, in our admittedly limited material.

A striking result of our study is, however, the very lopsided overall distribution of recorded noun phrases with clausal modifiers, in one or both languages: of the total of 104 such noun phrases counted in our random sample from the ENPC, as many as 70 were from texts originating in English, only 34 from texts with their origin in Norwegian. This difference was found to be statistically significant at the 1 per cent level. As the proportion of these constructions which take clausal modifiers in Original $v s$. Translated texts is largely the same, this does reveal a tendency towards transfer from the source to the target language, i.e. a difference depending on the direction of the translation.

Presumably, Norwegian writers will want to express largely the same meanings as English writers do, but according to our results they are more apt to find other means of doing so than through the use of noun phrases with clausal modifiers. Scrutiny of several of the examples recorded from the ENPC suggested a clear tendency for the meanings of clausal modifiers in English to be expressed outside the same noun phrase in Norwegian, in line with the general tendency towards a higher degree of explicitness in the latter language.

An explicitness scale was suggested for the modification of nouns, ranging from explicit to compact reference as follows: 
1 Modification expressed outside same noun phrase

2 Finite clause as modifier

3 Non-finite clause as modifier

4 Verbless clause as modifier

5 Non-clausal modifier (adjective phrases, prepositional phrases)

On the whole, Norwegian noun phrases seem to place themselves higher up this scale than English noun phrases do. To reach anything approaching full answers to some of the questions posed, a more rigid quantitative investigation is called for, with a broader data base.

\section{ACKNOWLEDGEMENTS}

I should like to acknowledge my indebtedness to two anonymous reviewers for their very useful comments on an earlier version of this article.

CORPORA

Oslo Multilingual Corpus, http://www .hf . uio.no/ilos/tjenester/kunnskap/ sprak/omc/

The Multiple-translation Corpus (1997-1999), Dept. of British and American Studies, University of Oslo (http://www.hf .uio.no/ilos/tjenester/kunnskap/ sprak/omc/enpc/multtrans .html). Compiled by Linn Øverås and Stig Johansson in connection with the English-Norwegian Parallel Corpus.

CORPUS TOOL

'Phrases in English', http: //phrasesinenglish.org/

REFERENCES

Behrens, B. This volume. Nominalization: A Case Study of Linguistic text conventions in comparable and parallel texts: English and Norwegian. In S. O. Ebeling, A. Grønn, K. R. Hauge \& D. Santos (eds.), Corpus-based Studies in Contrastive Linguistics, vol. 6(1) Oslo Studies in Language, University of Oslo.

Biber, D., S. Johansson, G. Leech, S. Conrad \& E. Finegan. 1999. Longman Grammar of Spoken and Written English. London: Longman.

Dirdal, $\mathrm{H}$. This volume. Individual variation between translators in the use of clause building and clause reduction. In S. O. Ebeling, A. Grønn, K. R. Hauge \& D. Santos (eds.), Corpus-based Studies in Contrastive Linguistics, vol. 6(1) Oslo Studies in Language, University of Oslo. 
Doherty, M. 2004. SAP - a strategy of attributive parsimony and its constraints characterizing translations between English and German. SPRIKreports, reports of the project Languages in Contrast (Språk $i$ kontast) 24.22 pages.

Faarlund, J. T., S. Lie \& K.I. Vannebo. 1997. Norsk referansegrammatikk. Oslo: Universitetsforlaget.

Fabricius-Hansen, C. 1998. Informational density and translation, with special reference to German - Norwegian - English. In S. Johansson \& S. Oksefjell (eds.), Corpora and Cross-linguistic Research: Theory, Method, and Case Studies, 197-234. Amsterdam: Rodopi.

Hasselgård, H., S. Johansson \& P. Lysvåg. 2012. English Grammar: Theory and Use (2nd edn.). Oslo: Universitetsforlaget.

Johansson, S. 2007. Seeing Through Multilingual corpora: On the Use of Corpora in Contrastive Studies. Amsterdam: John Benjamins.

Johansson, S. \& P. Lysvåg. 1987. Understanding English Grammar II: A Closer View. Oslo: Universitetsforlaget.

Plank, F. (ed.). 2003. Noun phrase Structure in the Languages of Europe. Berlin and New York: Mouton de Gruyter.

Quirk, R., S. Greenbaum, G. Leech \& J. Svartvik. 1985. A Comprehensive Grammar of the English Language. London: Longman.

Steiner, E. 2005. Explicitation, its lexicogrammatical realization, and its determining (independent) variables - towards an empirical and corpus-based methodology. SPRIKreports, reports of the project Languages in Contrast (Språk $i$ kontast) 36. 42 pages.

AUTHOR CONTACT INFORMATION

Johan Elsness

Department of Literature, Area Studies and European Languages

University of Oslo

Norway

johan.elsness@ilos.uio.no 